\title{
Factors affecting In vitro methane production from cecum contents of White Roman geese
}

\author{
Y.H. Chen ${ }^{1}$, J.C. $\mathrm{Hsu}^{2}$, S.Y. Wang ${ }^{3}$, P.H. Lin ${ }^{4}$, J. Perez ${ }^{5}$ \& H.W. Kuo ${ }^{5,6 \#}$ \\ ${ }^{1}$ Department of Animal Science and Biotechnology, Tunghai University. Taichung, Taiwan \\ ${ }^{2}$ Department of Animal Science, National Chung Hsing University, Taichung, Taiwan \\ ${ }^{3}$ Graduate Institute of Biotechnology, Chinese Culture University, Taipei, Taiwan \\ ${ }^{4}$ Department of Animal Science, National Chiayi University, Chiayi, Taiwan \\ ${ }^{5}$ Sustainability Science and Engineering Program, Tunghai University, Taichung, Taiwan \\ ${ }^{6}$ Department of Environmental Science and Engineering, Tunghai University, Taichung, Taiwan
}

(Submitted 16 March 2020; Accepted 7 January 2021; Published 8 March 2021)

\begin{abstract}
Copyright resides with the authors in terms of the Creative Commons Attribution 4.0 South African License.
See: http://creativecommons.org/licenses/by/4.0/za

Condition of use: The user may copy, distribute, transmit and adapt the work, but must recognize the authors and the South African Journal of Animal Science.
\end{abstract}

\begin{abstract}
The goal of this research was to gain understanding of in vitro methane $\left(\mathrm{CH}_{4}\right)$ production from the cecal contents of White Roman geese under various incubation conditions. Five experiments were conducted to ascertain the effects of i) incubation time, ii) $\mathrm{pH}$, iii) the addition of formic acid to the culture media, iv) temperature, and v) the addition of salt to the nutritive liquid. Methane production increased significantly with the supplementation of formic acid in the culture fluid (Experiment III). Additionally, $\mathrm{CH}_{4}$ production Experiment $\mathrm{V}$ was higher than that without saline. In contrast, low $\mathrm{CH}_{4}$ production occurred under acidic conditions $(\mathrm{pH} \leqq 5.4)$ and at temperatures higher or lower than typical bird body temperature $\left(43^{\circ} \mathrm{C}\right)$ without formic acid and saline solution in the culture media. Since bird body temperature cannot be controlled easily, approaches such as maintaining cecum fluid at low $\mathrm{pH}$ and preventing the formation of formic acid by adjusting the recipes of feeds could be considered for controlling in vivo $\mathrm{CH}_{4}$ production from the intestinal tract digesta of geese.
\end{abstract}

Keywords: body temperature, formic acid, geese farm, methane emission, saline solution

\#Corresponding author: hwkuo@thu.edu.tw

\section{Introduction}

Among the greenhouse gases (GHGs), $\mathrm{CH}_{4}$ is a major contributor to global warming effects (Naqvi \& Sejian, 2011). It is expected to contribute about $18 \%$ of total annual GHG emissions (Milich, 1999; Forabosco et al., 2017). Major $\mathrm{CH}_{4}$ emission sources include landfills, sediment, natural wetlands, flooded paddy fields, sewage treatment works, animal enteric fermentation, and anaerobic fermentation of agricultural wastes (Yang et al., 2003). Among these, animal enteric fermentation has been considered the main source of $\mathrm{CH}_{4}$ production via the digestion processes of ruminants (e.g. cattle, goats and sheep) and non-ruminants (e.g. hogs, horses, chickens, ducks, and geese) (Du Toit et al., 2013; Rendón-Huerta et al., 2018). Additionally, $\mathrm{CH}_{4}$ production from manure produced in the livestock and poultry industries is a major GHG source (Yang et al., 2003; Zhou et al., 2007; Wang et al., 2017). Geese ceca are major places for in vivo $\mathrm{CH}_{4}$ production (Chen et al., 2009; Chen et al., 2014). Chen et al. (2003) showed $\mathrm{CH}_{4}$ production from caecectomized geese was only $8-10 \%$ of that of sham-operated geese.

In the gastrointestinal systems of ruminant and non-ruminant animals, the cecum provides a habitat for growing microbes that can transform some dietary fibres symbiotically into short-chain fatty acids to provide energy (Gasaway, 1976a, 1976b; Herd \& Dawson, 1984). As a result of microbial metabolism, nonprotein nitrogen can be synthesized into amino acids and proteins that can be further digested and absorbed by poultry (Bjornhag \& Sperber, 1977; Morternsen \& Tindall, 1981). Nutrients of cecal contents in poultry can be fermented and converted into short-chain (2 - 5 carbons) fatty acids and biogas (e.g. ammonia, carbon dioxide and $\mathrm{CH}_{4}$ ) by microorganisms (Marounek et al., 1999; Chen et al., 2014). Besides, microorganisms cultured from poultry and cattle can generate $\mathrm{CH}_{4}$ (Van Kessel \& Russell, 1996; Montagna et al., 2019), suggesting that microorganisms in poultry ceca and bovine rumen fluids have similar functions. Nonetheless, 
the $\mathrm{CH}_{4}$ production rates from these microbes could differ because of niche conditions ( $\mathrm{pH}$ and temperature) for diverse animal enteric systems and in vitro tests. Better understanding of $\mathrm{CH}_{4}$ production from animal enteric systems would be helpful in attaining sustainable strategies to lower $\mathrm{CH}_{4}$ emission from poultry farms (Montagna et al., 2019).

Van Kessel and Russell (1996) reported that in vitro $\mathrm{CH}_{4}$ production rates from rumen fluid increased after a period of incubation, but the trend did not follow a linear relationship, probably because of changes of $\mathrm{pH}$ in the batches. Chen et al. (2009) showed that in vivo formic acid was the precursor of $\mathrm{CH}_{4}$ in geese, and the $\mathrm{pH}$ value in the goose ceca typically ranged between 6.21 and 6.51. However, the effects of $\mathrm{pH}$ values and formic acid concentrations on in vitro $\mathrm{CH}_{4}$ generation from goose cecal fluid have not been studied fully, making precise estimation of overall $\mathrm{CH}_{4}$ emission from geese difficult (Zhou et al., 2007). In addition, little is known about the potential influence of other environmental factors (e.g. temperature and salinity) on the methanogenesis of their cecal contents. An incubation temperature of $39{ }^{\circ} \mathrm{C}$ was used to investigate methanogenesis of cecal content fermentation of chickens (Tsukahara \& Ushida, 2000) and cows (Van Kessel \& Russell, 1996; Lalla et al., 1998), whereas $38^{\circ} \mathrm{C}$ was used for geese (Chen et al., 2014). Waterfowl (e.g. swans, geese, and ducks) usually have higher body temperatures, ranging from $40^{\circ} \mathrm{C}$ to $43^{\circ} \mathrm{C}$ (Stanier et al., 1984; Whittow, 1986), but $\mathrm{CH}_{4}$ production from the cecal contents of geese under various in vitro incubation temperatures has not been fully addressed, nor has salinity in the culture media (Chen et al., 2014). Accordingly, this study aimed to investigate the effects of incubation conditions (times, $\mathrm{pH}$, temperature, formic acid concentration, and the presence of saline) on $\mathrm{CH}_{4}$ production from the cecal fluid of White Roman geese to achieve strategies to lower $\mathrm{CH}_{4}$ emission and global warming.

\section{Material and Methods}

All the experimental birds were slaughtered at an official slaughterhouse using humane approaches, which are regulated under the Animal Industry Act of 1989 and the Animal Protection Act of 1998 of Taiwan (home slaughter has been forbidden since 1990s). The animal use protocol was approved by the Institutional Animal Care and Use Committee (IACUC) of Tunghai University (THU), Taichung, Taiwan (THU IACUC Approval Number 109-58).

Five experiments were conducted (Table 1). A total of 40 (10, 15, and 15 geese for Experiments I, II, and III, respectively) 14-week-old White Roman geese were used as experimental birds. They were raised in poultry houses and fed a commercial pellet finisher diet (Table 2) with water supplied ad libitum. For Experiments IV and V, fluids were sampled from the ceca of another twenty (10 for each experiment) 14week-old White Roman geese that were harvested at a local poultry slaughterhouse.

Table 1 Description of five experiments evaluating $\mathrm{CH}_{4}$ production from cecum fluid with factors and conditions for each experiment shown in Italics

\begin{tabular}{|c|c|c|c|c|c|c|}
\hline & $\begin{array}{c}\text { Source of } \\
\text { cecum fluid }\end{array}$ & $\begin{array}{l}\text { Incubation } \\
\text { time, hours }\end{array}$ & $\mathrm{pH}$ & $\begin{array}{l}\text { Formic } \\
\text { acid }\end{array}$ & $\begin{array}{c}\text { Temperature, } \\
{ }^{\circ} \mathrm{C} \\
\end{array}$ & Culturing media \\
\hline I & $\begin{array}{l}10 \text { laboratory } \\
\text { geese }\end{array}$ & $0,1,2,3,4$ & $\sim 8.34$ & 0 & 38 & $1 \times$ nutritive solution \\
\hline II & $\begin{array}{l}15 \text { laboratory } \\
\text { geese }\end{array}$ & 3 & $\begin{array}{l}2.4,5.4,6.0 \\
6.5,7.7,8.8\end{array}$ & 0 & 38 & $1 x$ \\
\hline III & $\begin{array}{l}15 \text { laboratory } \\
\text { geese }\end{array}$ & 3 & $\begin{array}{l}5.4,6.0,6.3 \\
6.5,7.1,7.5\end{array}$ & $\begin{array}{l}\sim 0.06 \% \\
v / v\end{array}$ & 38 & $1 x$ \\
\hline IV & $\begin{array}{l}10 \text { market } \\
\text { geese }\end{array}$ & 4 & 8.34 & 0 & $\begin{array}{l}28,33,38,43 \\
48\end{array}$ & $1 x$ \\
\hline V & $\begin{array}{l}10 \text { market } \\
\text { geese }\end{array}$ & 4 & $\begin{array}{l}8.34 \text { for saline } \\
\text { solution; } 6.35 \text { for } \\
\text { nutritive solution }\end{array}$ & 0 & 43 & $\begin{array}{l}1 \times \text { or } 0.5 \times \text { nutritive } \\
\text { solution, } 0.9 \% \text { saline, or } \\
\text { distilled water }\end{array}$ \\
\hline
\end{tabular}


Table 2 Ingredients and nutritional value of the diet fed to growing geese

\begin{tabular}{lc}
\hline Ingredients, \% & Finishing diet (12-14 weeks old) \\
\hline Yellow corn meal & 58.02 \\
Wheat flour middling & 10.00 \\
Full fat soybean meal & 10.00 \\
Soybean meal, 44\% & 12.00 \\
Fish meal, 60\% & 5.00 \\
Di-calcium phosphate & 1.00 \\
Calcium carbonate, pulverized & 1.20 \\
Lard & 2.00 \\
Salt & 0.40 \\
DL-Methionine & 0.10 \\
Choline chloride, $50 \%$ & 0.08 \\
Premix ${ }^{1}$ & 0.20 \\
Calculated nutritional value & \\
Metabolizable energy, kcal/kg & 3010 \\
Crude protein, \% & 20.00 \\
Crude fibre, \% & 6.50 \\
Calcium, $\%$ & 0.92 \\
Available phosphorus, \% & 0.42
\end{tabular}

${ }^{1}$ Per kilogram of diet: vitamin $A: 15,000 \mathrm{IU}$, vitamin $D_{3}: 3,000 \mathrm{IU}$, vitamin $\mathrm{E}: 30 \mathrm{mg}$, vitamin $\mathrm{K}_{3}: 4 \mathrm{mg}$, vitamin $\mathrm{B}_{2}: 8 \mathrm{mg}$, vitamin $\mathrm{B}_{6}: 5 \mathrm{mg}$, vitamin $\mathrm{B}_{12}: 25 \mathrm{mcg}$, Ca-pantothenate: $19 \mathrm{mg}$, niacin: $50 \mathrm{mg}$, folic acid: $1.5 \mathrm{mg}$, biotin: $60 \mathrm{mcg}$, iron: $153 \mathrm{mg}$, manganese: $200 \mathrm{mg}$, copper: $17.64 \mathrm{mg}$, magnesium: $25.3 \mathrm{mg}$, selenium: $0.25 \mathrm{mg}$, zinc: $105.8 \mathrm{mg}$, cobalt: 0.4 $\mathrm{mg}$

The aim of Experiment I was to study the $\mathrm{CH}_{4}$ production (accumulative amount) from the cecal contents of White Roman geese under six incubation times $(0,0.3,1,2,3$, and 4 hours) $(n=5)$. The test for each incubation time had five replicates. Ten randomly selected 14-week-old birds were slaughtered to collect a mixture of cecal contents. In each test, $1 \mathrm{~g}$ cecal content was put into a $15-\mathrm{mL}$ vial containing 3.25 $\mathrm{mL}$ of full-strength (1x) nutritive buffer solution (Salvador et al., 1993). The vials were filled with $100 \% \mathrm{CO}_{2}$, sealed with butyl rubber stoppers and aluminium caps, and incubated in a $38{ }^{\circ} \mathrm{C}$ shaker $(80 \mathrm{rpm})$ under anaerobic conditions. At the end of each incubation time, $0.2 \mathrm{~mL}$ of $10 \%$ chloride mercury $\left(\mathrm{HgCl}_{2}\right)$ was added to the vials to terminate bacterial activity. Biogas from each test was sampled from the vial with a gas-tight syringe to measure $\mathrm{CH}_{4}$ concentration.

Experiment II was designed to study the in vitro effect of six pH values $(2.4,5.4,6.0,6.5,7.7$, and 8.8) on $\mathrm{CH}_{4}$ production from the cecal contents. A total of 18 tests $(\mathrm{n}=3)$ (triplicate for each $\mathrm{pH}$ test) were conducted in $15-\mathrm{mL}$ vials, each containing $1 \mathrm{~g}$ cecal content and $3.25 \mathrm{~mL}$ mixed nutritive buffer solution in which $\mathrm{pH}$ was adjusted to intended values with $10 \%$ sodium hydroxide $(\mathrm{NaOH})$ or $6 \mathrm{~N}$ hydrochloric acid (Van Kessel \& Russell, 1996). The $\mathrm{pH}$ values were measured with a pH sensor and meter system (Hanna HI model 8424; Hanna Instruments, Inc., Woonsocket, Rhode Island). The incubation time was three hours. Other preparation conditions were the same as Experiment I.

The aim of Experiment III was to study how supplementation of formic acid affected in vitro $\mathrm{CH}_{4}$ production from the cecal contents of the geese (15 randomly selected birds) at seven levels of $\mathrm{pH}(5.4,6.0$, 6.3, 6.5, 7.1, 7.5, and 8.3). Each condition was evaluated in triplicate. Experimental preparations were similar to those of Experiments I and II, except for the supplementation of $2 \mu \mathrm{L}$ formic acid (98\%) (Merck, NJ, USA) to the 3.25-mL mixed nutritive buffer solution.

The purpose of Experiment IV was to study the in vitro $\mathrm{CH}_{4}$ production from the cecal contents of the geese (collected from 10 randomly selected birds) under five incubation temperatures $\left(28^{\circ} \mathrm{C}, 33^{\circ} \mathrm{C}, 38^{\circ} \mathrm{C}\right.$, $43^{\circ} \mathrm{C}$ and $48{ }^{\circ} \mathrm{C}$ ). Each of the temperature conditions was evaluated in triplicate. Most experimental preparations were as described, whereas an incubation time of four hours and a $\mathrm{pH}$ of 8.34 were used.

In Experiment $\mathrm{V}$, in vitro $\mathrm{CH}_{4}$ production was tested in triplicate with four culture fluids $(3.25 \mathrm{~mL}$ of $1 \times$ nutritive buffer solution, half strength $(0.5 x)$ nutritive buffer solution, $0.9 \%$ physiology saline solution, and 
distilled water only). Most of experimental preparations were the same as described above, whereas a pH of 6.35 (for saline solution), a pH of 8.34 (for nutritive solution), a temperature of $43^{\circ} \mathrm{C}$, and four hours' incubation were used.

Methane was measured with gas chromatography (Shimadzu, model 14 B) with a FID (flame ionization detector) and a column packed with Porapak Q (Supelco, PA, USA). The oven temperature was $70{ }^{\circ} \mathrm{C}$ and the temperature for injection and detector was $130^{\circ} \mathrm{C}$. Nitrogen gas was used as the carrier gas with a flow rate of $10 \mathrm{~mL} / \mathrm{min}$. Standards of $\mathrm{CH}_{4}(0.5,10,50,100,500$, and $1000 \mathrm{ppm})$ were prepared by diluting stock $\mathrm{CH}_{4}$ gas (95.5\%) (China Petroleum Co.) with nitrogen gas $(98.5 \%)$ to construct a calibration curve to determine $\mathrm{CH}_{4}$ concentration in each test. The linear calibration curve for $\mathrm{CH}_{4}$ had a $\mathrm{R}^{2}$ value > 0.998 and a coefficient of variation $(\mathrm{CV})<4.7 \%$. Detection of $\mathrm{CH}_{4}$ from $100-\mathrm{ppm}$ standard was used for quality control as the $\mathrm{CV}$ value was kept $<10 \%$. The amount of $\mathrm{CH}_{4}$ production for each batch was then expressed as microgram $\mathrm{CH}_{4}$ accumulated per gram of cecal content $(\mu \mathrm{g} / \mathrm{g})$, whereas $\mathrm{CH}_{4}$ production rate was shown as microgram $\mathrm{CH}_{4}$ per gram of cecal contents per hour $(\mu \mathrm{g} / \mathrm{g} / \mathrm{h})$.

The SAS software was used for statistical analysis (SAS Institute Inc., Cary, North Carolina, USA). Least square means were used to estimate the differences between treatments in each experiment.

\section{Results and Discussion}

Results from Experiment I showed amounts of $\mathrm{CH}_{4}$ accumulated for longer incubation times (181.4 and $188.4 \mathrm{ug} / \mathrm{g}$ for three- and four-hour tests, respectively) were significantly higher than those for shorter incubation times (9.9 and $65.8 \mathrm{ug} / \mathrm{g}$ for 0.3 - and 1-hour tests) (Figure 1). Nonetheless, $\mathrm{CH}_{4}$ production seemed to reach saturated level after 3-4 hours incubation, as shown in the notable decrease of $\mathrm{CH}_{4}$ production during this 0 period (Figure 1, bar chart). Only a little $\mathrm{CH}_{4}$ was produced after three hours of incubation, probably because of the gradual exhaustion of substrate in the cecal contents supplied for methanogenesis. In this study, a maximum $\mathrm{CH}_{4}$ production rate of $4.85 \mu \mathrm{mole} / \mathrm{g} / \mathrm{h}$ (or $77.6 \mu \mathrm{g} / \mathrm{g} / \mathrm{h}$ ) (Figure 1 , bar chart) occurred during incubation times of 0.3 - 1 hour. In previous studies, $\mathrm{CH}_{4}$ production rates were $3.5-10.3 \mu \mathrm{mole} / \mathrm{g} / \mathrm{h}$ for rumen contents (Hungate et al., 1970), $0.1-0.3 \mu \mathrm{mole} / \mathrm{g} / \mathrm{h}$ for ceca of rats, and 8.2 - $11.4 \mu \mathrm{mole} / \mathrm{g} / \mathrm{h}$ for chicken (Tsukahara \& Ushida, 2000). These findings suggest that $\mathrm{CH}_{4}$ production from cecum and rumen contents for various animals could be affected by culturing conditions and even microbial community structures in testing mixtures.

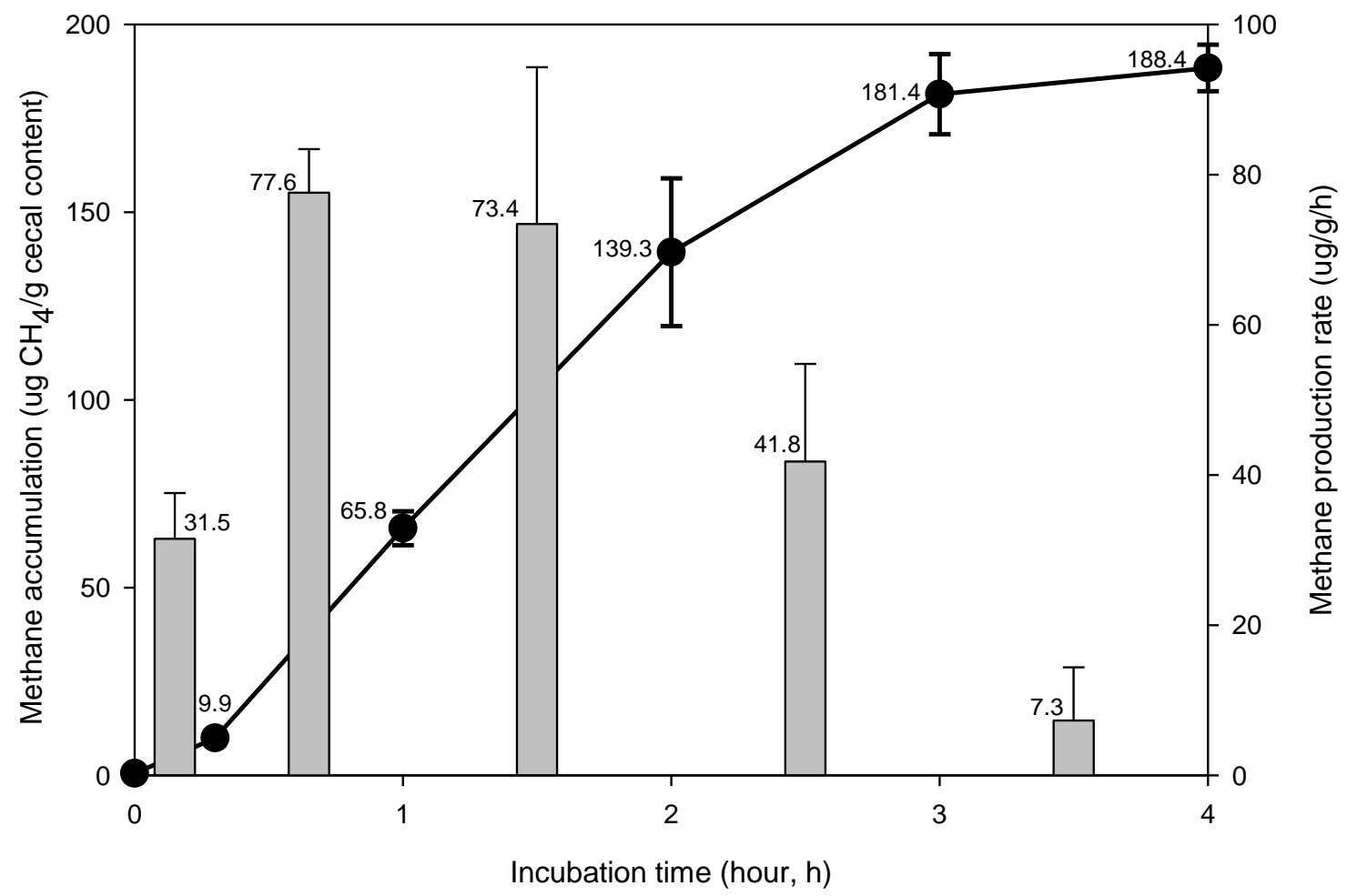

Figure 1 Methane accumulative production (line and scatter plot, primary y axis) and methane production rate (bar chart, secondary y axis) of cecum contents in geese at different incubation times 
Methane production varied after three hours' incubation under different initial $\mathrm{pH}$ (Figure 2). Results showed that the $\mathrm{CH}_{4}$ production for low pH (2.4 and 5.4) batches was significantly lower than for $\mathrm{pH} 6.0$ 8.8. A maximum $\mathrm{CH}_{4}$ production was recorded at a pH of 6.5 , but did not show statistical difference $(P>0.05)$ from those for $\mathrm{pH} 6.0,7.7$, and 8.8. In contrast, little $\mathrm{CH}_{4}$ was produced under acid conditions $(\mathrm{pH} \leq 5.4)$. Amount of $\mathrm{CH}_{4}$ produced after three hours' incubation at pH $5.4(16.4 \mu \mathrm{g} / \mathrm{g})$ was about five times lower $(P$ $<0.05)$ than for $\mathrm{pH} 6.0(83.4 \mathrm{\mu g} / \mathrm{g})$, suggesting acid conditions would inhibit $\mathrm{CH}_{4}$ production from goose cecum contents, whereas the $\mathrm{pH}$ range from 6.0 to 8.8 was relatively more suitable for bacteria activity correlated with $\mathrm{CH}_{4}$ production.

The considerable decrease in $\mathrm{CH}_{4}$ production from geese cecum contents between pH 6.0 and pH 5.4 in this study was similar to a study on cow rumen contents, which showed $\mathrm{CH}_{4}$ production decreased rapidly at pH lower than 6.5 (Van Kessel \& Russell, 1996). Another study suggested that methanogenic bacteria were sensitive to $\mathrm{pH}$ changes (Fahey \& Berger, 1988), probably owing to changes in availability of the hydrogen ion $\left(\mathrm{H}^{+}\right)$involved in the microbial metabolism pathway. Besides, low $\mathrm{pH}$ conditions would possibly affect acidifying bacteria to convert carbonaceous substrates in cecum contents and culture fluid to shortchain fatty acids (SCFAs) (e.g. formic acid, acetic acid, and propionic acid) - intermediates for anaerobic fermentation and reactants for $\mathrm{CH}_{4}$ production. Consequently, in the culturing mixture, changes in acetate to propionate ratio would occur, which has been suggested to have a high correlation with $\mathrm{pH}$ of rumen fluid and capacity of bacteria in producing $\mathrm{CH}_{4}$ from hydrogen and carbon dioxide (Lalla et al., 1998).

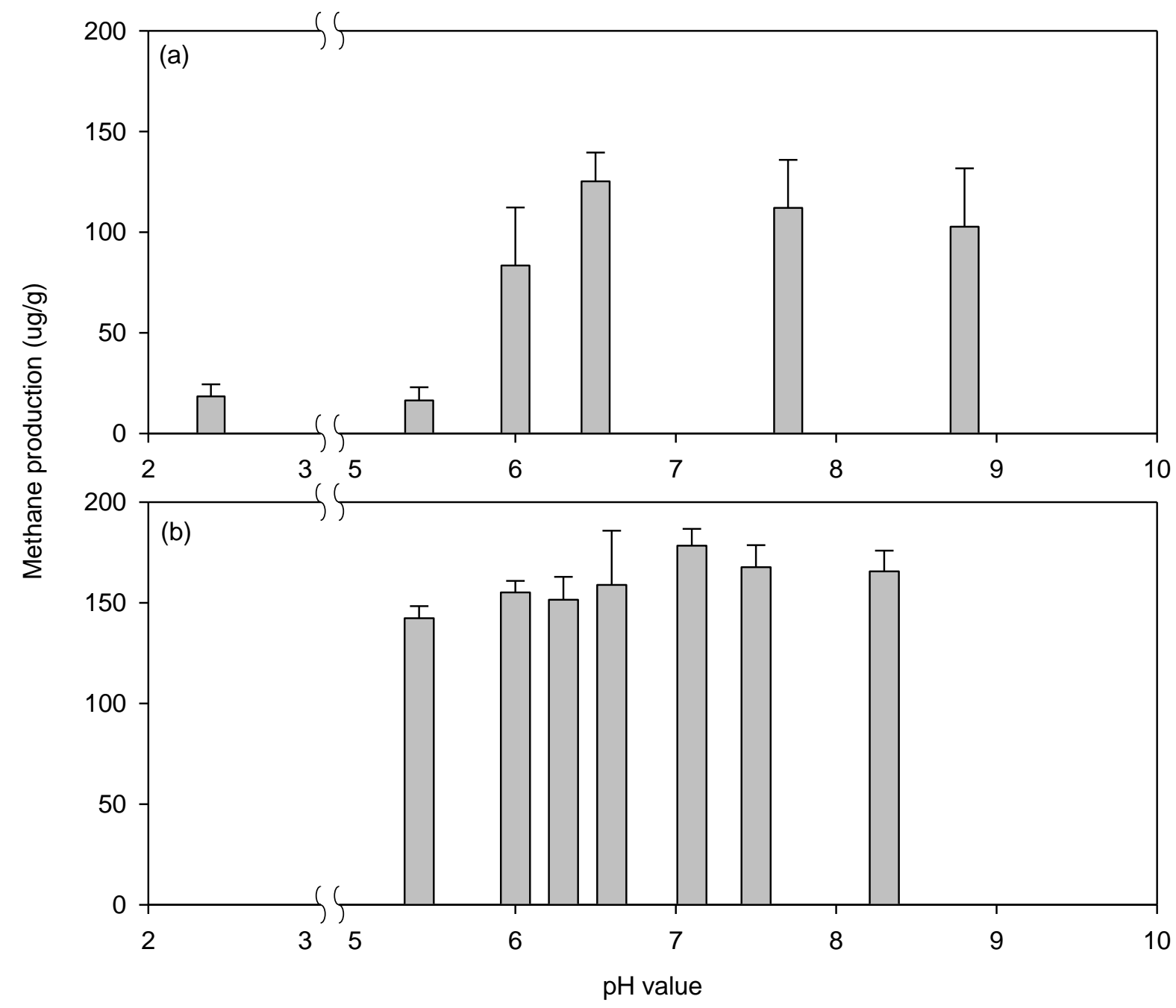

Figure 2 Methane production from cecum fluid of geese with different $\mathrm{pH}$ values without (a) or with (b) the addition of formic acid 
When formic acid was added to the culturing mixture, more $\mathrm{CH}_{4}$ was produced than in the previous tests without formic acid addition (Experiment II) (Figure 2b). The amount of $\mathrm{CH}_{4}$ produced under pH 5.4 8.3 after three hours' incubation ranged from 142.3 to $178.3 \mu \mathrm{g} / \mathrm{g}$. Maximum $\mathrm{CH}_{4}$ production was found under a $\mathrm{pH}$ of 7.1 , whereas $\mathrm{CH}_{4}$ production for other $\mathrm{pH}$ tests was rather lower, but not significant. Interestingly, under $\mathrm{pH} \mathrm{5.4,} \mathrm{CH}_{4}$ production from the test with formic acid $(142.3 \mu \mathrm{g} / \mathrm{g}$ ) (Figure $2 \mathrm{~b}$ ) seemed not to have been inhibited, as shown in Experiment II without formic acid (16.4 $\mu \mathrm{g} / \mathrm{g}$ ) (Figure 2a). This suggested that formic acid in the culturing fluid could still be converted into $\mathrm{CH}_{4}$ under a $\mathrm{pH}$ of 5.4 by methanogenic bacteria in cecal contents. The finding that low $\mathrm{pH}(5.4)$ restrained the capability of the acidification microorganisms for converting carbonaceous substrates in culturing fluid to short-chain fatty acids (including formic acid and acetic acid), but did not have much effect on methanogenic bacteria, as shown in Experiment III, among which most of the formic acid seemed to have been converted into $\mathrm{CH}_{4}$.

Methane production from the cecum contents was significantly different under various incubation temperatures (Table 3). The highest $\mathrm{CH}_{4}$ production $(1508.69 \pm 65.1 \mu \mathrm{g} / \mathrm{g})$ occurred at $43^{\circ} \mathrm{C}$, whereas the lowest $(65.01 \pm 184.32 \mu \mathrm{g} / \mathrm{g})$ happened at $28^{\circ} \mathrm{C}$. Low $\mathrm{CH}_{4}$ concentrations could be detected even right after preparation and at the beginning of incubation (time 0 ). Correlation between incubation temperatures and $\mathrm{CH}_{4}$ production followed linear and quadratic trends well $(P<0.001)$. These results demonstrated that more $\mathrm{CH}_{4}$ would be produced at $43{ }^{\circ} \mathrm{C}$, which was close to the typical temperature of the abdominal cavity of waterfowl (Whittow, 1986; Salvador et al., 1993). Interestingly, $\mathrm{CH}_{4}$ production for the cecum fluid from the local slaughterhouse was significantly different from that from laboratory poultry houses, although some testing conditions for Experiments IV and I were similar $\left(\mathrm{pH} \sim 8.34\right.$, temperature $38{ }^{\circ} \mathrm{C}$, and four hours' incubation). Amounts of $\mathrm{CH}_{4}$ produced in Experiment IV were much higher (about tenfold at $38^{\circ} \mathrm{C}$ ) than those from Experiments I, II, and III. It was surmised that the cecum contents sampled from the birds purchased from the local poultry processing farm had higher substrate contents or more active methanogenic bacteria than those from laboratory-grown birds. To minimize $\mathrm{CH}_{4}$ emission from geese, useful approaches would be to control the availability of substrates and the activity of methanogenic microbes.

Earlier studies showed different optimal temperatures for $\mathrm{CH}_{4}$ production from cow rumen fluid $\left(39^{\circ} \mathrm{C}\right)$ (Lalla et al., 1998), paddy field soil $\left(34.5^{\circ} \mathrm{C}\right)$ (Parashar et al., 1993), and subarctic peat soil $\left(25^{\circ} \mathrm{C}\right)($ Dunfield et al., 1993), which were all lower than the $43^{\circ} \mathrm{C}$ determined for geese cecum fluid in this study. It was surmised that microbial composition in the geese cecum fluid tested in this study would be different from samples used for previous studies. Microbial species or strains that were well-adapted to conditions in the ceca would become dominant in the cecum fluid samples and would show high $\mathrm{CH}_{4}$ production ability under a temperature close to typical bird body temperature. This may provide crucial ideas for suitable anaerobic microbes and optimal operating parameters for engineered processes for anaerobic biodegradation of particular waste. Such information could also be used to amend strategies for minimizing $\mathrm{CH}_{4}$ production from uncontrolled sources when $\mathrm{CH}_{4}$ gas was not considered for recovery as a biofuel source.

Table 3 Summary of methane productions from cecal contents of White Roman geese at incubation times of 0 and 4 hours under various incubation temperatures

\begin{tabular}{lcc}
\hline & \multicolumn{2}{c}{ Accumulated methane $(\mu \mathrm{g} / \mathrm{g})$} \\
\cline { 2 - 3 } Temperature, ${ }^{\circ} \mathrm{C}$ & $0 \mathrm{~h}$ & $4 \mathrm{hrs}$ \\
\hline 28 & $31.37 \pm 0.76$ & $663.01 \pm 184.32^{\mathrm{a}}$ \\
33 & $36.64 \pm 3.08$ & $1244.87 \pm 372.48^{\mathrm{b}}$ \\
38 & $39.57 \pm 4.00$ & $1508.69 \pm 65.10^{\mathrm{c}}$ \\
43 & $44.21 \pm 5.74$ & $2551.63 \pm 238.29^{\mathrm{d}}$ \\
48 & $36.77 \pm 0.86$ & $1279.64 \pm 110.54^{\mathrm{b}, \mathrm{c}}$ \\
\hline
\end{tabular}

$\overline{a, b, c, d}$ Methane production values with same superscript were not different with probability $P$-value $\geq 0.05$

Methane production after four hours' incubation from the batch tests with saline solution was higher than from those using $1 \times$ and half-strength nutritive buffer or just distilled water (Table 4). These results suggested that the nutritive buffer solution and saline solution enhanced $\mathrm{CH}_{4}$ production from the cecum contents. Interestingly, the batch using distilled water without nutritive buffer showed significant $\mathrm{CH}_{4}$ production (from $37.46 \mu \mathrm{g} / \mathrm{g}$ at time 0 to $718.63 \mu \mathrm{g} / \mathrm{g}$ at four hours). This implied that geese cecum fluids 
already contain nutrients that are required to metabolize anaerobic methanogenic microbes. Additions of $1 \times$ nutritive solution or $0.9 \%$ saline solution seemed to create better niche conditions for in vitro microbial $\mathrm{CH}_{4}$ production. In contrast, less rich (or oligotrophic) culturing conditions would result in lower $\mathrm{CH}_{4}$ production, which would ease a little the global warming effect of in vivo $\mathrm{CH}_{4}$ production from animal intestinal systems.

Table 4 Methane production from cecal contents of White Roman geese using various culture media

\begin{tabular}{lcc}
\hline \multirow{2}{*}{ Culture media } & \multicolumn{2}{c}{ Accumulated methane $(\mu \mathrm{g} / \mathrm{g})$} \\
\cline { 2 - 3 } & $0 \mathrm{~h}$ & $4 \mathrm{hrs}$ \\
\hline Saline & $27.63 \pm 4.19$ & $2267.69 \pm 108.27^{\mathrm{a}}$ \\
$1 \times$ nutritive solution & $33.96 \pm 3.70$ & $1479.58 \pm 69.35^{\mathrm{b}}$ \\
$0.5 \times$ nutritive solution & $30.61 \pm 0.89$ & $1227.86 \pm 133.30^{\mathrm{c}}$ \\
Distilled water & $37.46 \pm 2.18$ & $718.63 \pm 36.84^{\mathrm{d}}$ \\
\hline \multicolumn{2}{c}{ a,b,c,d Methane production values with same superscript were not different with probability $P$-value $\geq 0.05$} \\
1x: full strength, 0.5x half-strength
\end{tabular}

Since several heavy metals (e.g. zinc, copper, and manganese) were included in the nutritive solution as trace elements and different microbes may prefer certain optimal concentrations, inappropriate concentrations could lead to adverse effects on microbial activity. Earlier studies showed the toxicity of heavy metals on microorganisms (Chaudri et al., 1992; Giller et al., 1998). In addition, salt (sodium chloride) seemed to affect $\mathrm{CH}_{4}$ production, even when a nutritive buffer solution containing minerals was used broadly to test $\mathrm{CH}_{4}$ production from ruminal fluids (Van Kessel \& Russell, 1996), human faeces (Salvador et al., 1993), and chicken cecum fluids (Tsukahara \& Ushida, 2000). Methane production from the samples with saline solution $(0.9 \% \mathrm{w} / \mathrm{v})$ was about 1.53 times higher than from the samples using $1 \times$ nutritive solution (with a sodium chloride concentration of $0.047 \% \mathrm{w} / \mathrm{v}$ ). Besides, based on results from Experiment II, the saline solution with a pH of 6.35 would be more suitable for $\mathrm{CH}_{4}$ production than the nutritive solution with a $\mathrm{pH}$ of 8.34 .

\section{Conclusion}

Because bird body temperature cannot be regulated easily, maintaining the flow of caecum fluid at low $\mathrm{pH}$ and preventing the formation of formic acid by adjusting the diet might be considered when attempting to control in vivo $\mathrm{CH}_{4}$ production in the intestinal tract of geese. These findings provide insight into in vitro $\mathrm{CH}_{4}$ production from geese cecum fluids under various conditions and can be used for its estimation and control.

\section{Acknowledgements}

This study was financially supported by the Tunghai Green Energy Development and Management Institute (TGEI) of Tunghai University. The authors would like to express their gratitude to Miss Chi-Yin Chiou and Mr. Wen-Wan Kuo at the Department of Animal Science, Chinese Culture University, for their help with animal management, sample collection, and methane gas detection.

\section{Authors' Contributions}

CY-H (ORCID 0000-0002-8870-4103) designed the experiments, collected and analysed the data, and prepared the manuscript; HJ-C (ORCID 0000-0001-6158-196X) designed the experiments and supervised the progress of the studies; WS-Y (ORCID 0000-0003-1566-5542) collected and analysed the data; LP-H (ORCID 0000-0001-5140-1195) collected and analysed the data; JP (ORCID 0000-0002-5746-9542) prepared the manuscript; KH-WD (ORCID 00000002-7612-6879) participated in data analysis and manuscript preparation.

\section{Conflict of Interest Declaration}

There were no conflicts of interest regarding this work.

\section{References}

Bjornhag, G. \& Sperber, I., 1977. Transport of various food components through the digestive tract of turkey, geese, and guinea fowl. Swedish J. Agric. Res. 7, 57-66.

Chaudri, A.M., McGrath, S.P. \& Gille, K.E., 1992. Survival of the indigenous population of Rhizobium leguminosarum biovar trifolii in soil spiked with $\mathrm{Cd}, \mathrm{Zn}, \mathrm{Cu}$ and $\mathrm{Ni}$ salt. Soil Biol. Biochem. 24, 625-632. https://doi.org/10.1016/0038-0717(92)90040-5 
Chen, Y.H., Wang, S.Y. \& Hsu, J.C., 2003. Effects of caecectomy on body weight gain, intestinal characteristics and enteric gas production in goslings. Asian-Aust. J. Anim. Sci. 16, 1030-1034. DOI: 10.5713/ajas.2003.1030

Chen, Y.H., Wang, S.Y. \& Hsu, J.C., 2009. In vivo methane production from formic and acetic acids in the gastrointestinal tract of White Roman geese. Asian-Aust. J. Anim. Sci. 2009; 22(7), 1043-1047. DOI: 10.5713/ajas.2009.80319

Chen, Y.H., Lee, S.M., Hsu, J.C., Chang, Y.C. \& Wang, S.Y., 2014. Methane generation from the intestine of Muscovy ducks, mule ducks and White Roman geese. Aerosol Air Qual. Res. 14, 323-329. DOI: 10.4209/AAQR.2013.05.0180

Du Toit, C.J.L., Van Niekerk, W.A. \& Meissner, H.H., 2013. Direct greenhouse gas emissions of the South African small stock sectors. S. Afr. J. Anim. Sci. 43(3), 340-361. DOI: 10.4314/sajas.v43i3.8

Dunfield, P., Knowles, R., Dumont, R. \& Moore, T.R., 1993. Methane production and consumption in temperate and subArctic peat soils: Response to temperature and pH. Soil Biol. Biochem. 25, 321-326. https://doi.org/10.1016/0038-0717(93)90130-4

Fahey, G.C. Jr. \& Berger L.L., 1988. Carbohydrate nutrition of ruminants. In: D.C. Church (ed). The ruminant animal digestive physiology and nutrition. Prentice Hall, New Jersey, USA.

Forabosco, F., Chitchyan, Z.H. \& Mantovani, R., 2017. Methane, nitrous oxide emissions and mitigation strategies for livestock in developing countries: A review. S. Afr. J. Anim. Sci. 47(3), 268-280. http://dx.doi.org/10.4314/sajas.v47i3.3

Gasaway, W.C., 1976a. Seasonal variation in diet, volatile fatty acid production and size of the cecum of rock ptarmigan. Comp. Biochem. Physiol. 54A, 109-114. https://doi.org/10.1016/S0300-9629(76)80021-7

Gasaway, W.C., 1976b. Volatile fatty acids and metabolizable energy derived from cecal fermentation in the willow ptarmigan. Comp. Biochem. Physiol. 53A, 115- 121. DOI: 10.1016/s0300-9629(76)80022-9

Giller, K.E., Witter, E. \& McGrath, S.P., 1998. Toxicity of heavy metals to microorganisms and microbial processes in agricultural soils: A review. Soil Biol. Biochem. 30, 1389-1414. https://doi.org/10.1016/S0038-0717(97)00270-8

Herd, R. \& Dawson, T., 1984. Fiber digestion in the emu, Dromaius novaehollandiae, a large bird with a simple gut and high rates of passage. Physiol. Zool. 57, 70-84. https://doi.org/10.1086/physzool.57.1.30155970

Hungate, R.E., Smith, W., Bauchop, T., Yu, I. \& Rabinowitz, J.C., 1970. Formate as an intermediate in the bovine rumen fermentation. J. Bacteriol. 102, 389- 397. DOI: 10.1128/JB.102.2.389-397.1970

Lalla, R.P., Russell, J.B. \& Van Aniburgh, M.E., 1998. The role of $\mathrm{pH}$ in regulating ruminal methane and ammonia production. J. Anim. Sci. 76, 2190-2196 DOI: 10.2527/1998.7682190x

Marounek, M., Suchorska, O. \& Savka, O., 1999. Effect of substrate and feed antibiotics on in vitro production of volatile fatty acids and methane in caecal contents of chickens. Anim. Feed Sci. Technol. 80, $223-230$. https://doi.org/10.1016/S0377-8401(99)00065-6

Milich, L., 1999. The role of methane in global warming: Where might mitigation strategies be focused? Global Environ. Change 9, 179-201. https://doi.org/10.1016/S0959-3780(98)00037-5

Montagna, F., Scripnic, E. \& Forabosco, F., 2019. Intensification of production, low emission pathways and sustainable strategies for backyard, layer and broiler chickens. S. Afr. J. Anim. Sci. 49(3), 534-545. http://dx.doi.org/10.4314/sajas.v49i3.14

Mortensen, A. \& Tindall, A. 1981. Caecal decomposition of uric acid in captive and free ranging willow ptarmigan (Lagopus lagopus lagopus). Acta Physiol. Scand. 111, 129- 133. DOI: 10.1111/j.1748-1716.1981.tb06715.x

Naqvi, S.M.K. \& Sejian, V., 2011. Global climate change: Role of livestock. Asian J. Agric. Sci. 3(1), 19-25. https://www.researchgate.net/publication/49605076

Parashar, D.C., Gupta, P.K., Rai, J., Sharma, R.C. \& Singh, N., 1993. Effect of soil temperature on methane emission from paddy fields. Chemosphere 26, 247-250. https://doi.org/10.1016/0045-6535(93)90425-5

Rendón-Huerta, J.A., Pinos-Rodriguez, J.M., Kebreab, E., Garcia-López, J.C. \& Vicente, J.G., 2018. Comparison of greenhouse gas emissions from Mexican intensive dairy farms. S. Afr. J. Anim. Sci. 48(1), 48-55. http://dx.doi.org/10.4314/sajas.v48i1.6

Salvador, V., Cherbut, C., Barry, J.L., Bertrand, D., Bonnet, C. \& Delort-Laval, J., 1993. Sugar composition of dietary fibre and short-chain fatty acid production during in vitro fermentation by human bacteria. Br. J. Nutr. 70, 189-197. DOI: 10.1079/bjn19930116

Stanier, M.W., Mount, L.E. \& Bligh, J., 1984. Energy balance and temperature regulation. Cambridge University Press, Cambridge.

Van Kessel, J.S. \& Russell, J.B., 1996. The effect of pH on ruminal methanogenesis. FEMS Microbiol. Ecol. 20, 205210. https://doi.org/10.1111/j.1574-6941.1996.tb00319.x

Wang, L.-Z., Xue, B. \& Yan, T., 2017. Greenhouse gas emissions from pig and poultry production sectors in China from 1960 to 2010. J. Integr. Agric. 16(1), 221-228. DOI: 10.1016/S2095-3119(16)61372-2

Whittow, G.C., 1986. Regulation of body temperature. In: P.D. Strukie (ed). Avian physiology. Springer-Verlag, New York.

Yang, S.S., Liu, C.M. \& Liu, Y.L., 2003. Estimation of methane and nitrous oxide emission from animal production sector in Taiwan during 1999-2000. Chemosphere 52, 1381-1388. DOI: 10.1016/S0045-6535(03)00473-9

Zhou, J.B., Jiang, M.M. \& Chen, G.Q., 2007. Estimation of methane and nitrous oxide emission from livestock and poultry in China during 1949-2003. Energy Policy 35, 3759-3767. https://doi.org/10.1016/j.enpol.2007.01.013 